\title{
Diaprepes root weevil, a new California pest, will raise costs for pest control and trigger quarantines
}

by Karen M. Jetter and Kris Godfrey

This study presents an economic analysis of cost increases for citrus, avocado and nursery producers should the Diaprepes root weevil become established in California. First identified in Southern California in 2005, Diaprepres would mainly affect orange, grapefruit, lemon and avocado crops. The primary impacts would be increased production costs for pest treatments and increased harvesting costs to conform to quarantine regulations, in particular to ship ornamental plants out of infested regions. The estimated increase in production cost to treat Diaprepes was $\$ 609$ per acre on average for citrus and avocado and \$525 per acre for infested nurseries. The average increase in total cost as a share of revenues was $\mathbf{2 1 . 6 1 \%}$ for oranges, $11.35 \%$ for avocados, $9.80 \%$ for grapefruit and $5.62 \%$ for lemons; for nursery growers it was less than $1 \%$.

7 he Diaprepes root weevil was first 1 identified in California in 2005 in urban areas of Orange and Los Angeles counties, and in fall 2006 it was found in San Diego County. These areas were initially subject to state-run eradication and quarantine programs in an attempt to eliminate existing populations of the weevil and to limit its spread to other parts of the state. In July 2008, the eradication program ended due to lack of funding, while quarantine efforts remain in effect. If the current quarantine program is not successful in containing Diaprepes root weevil (Diaprepes abbreviatus Coleoptera: Curculionidae) it will spread, causing economic losses to growers in all areas that can support infestations. This study presents an analysis of the economic effects for

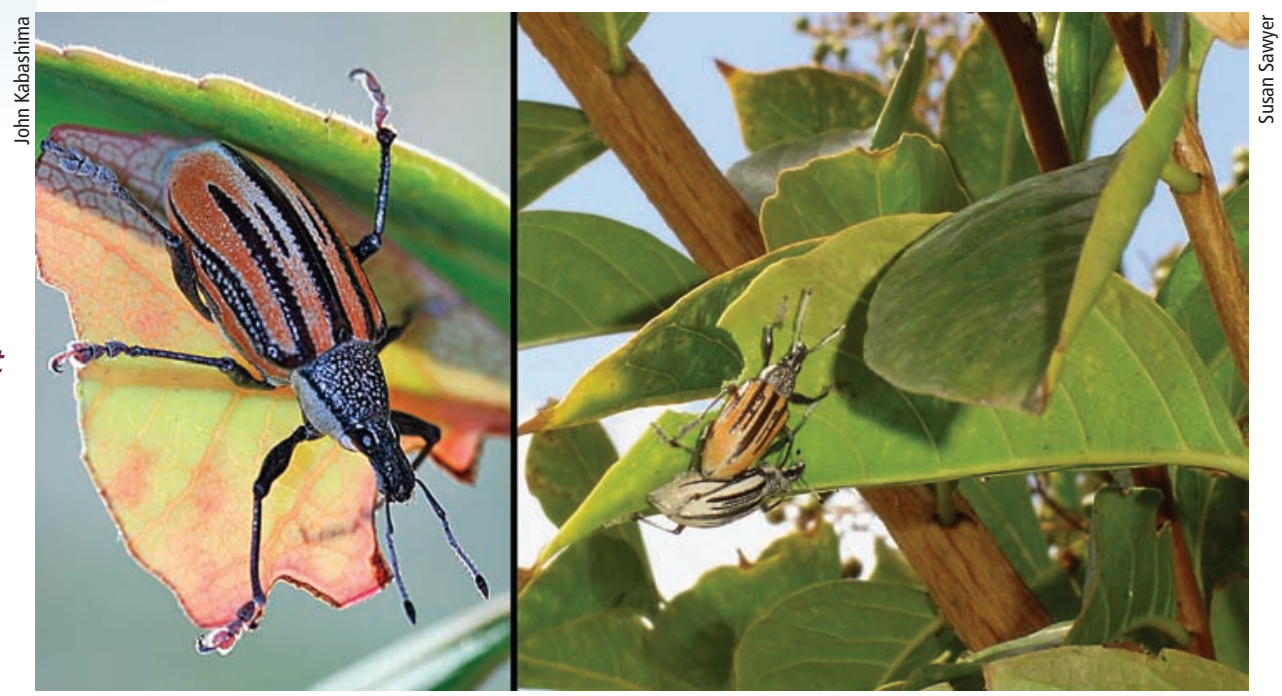

The Diaprepres root weevil, native to the Caribbean, was first identified in California in 2005. Left, an adult feeds on a Raphiolepsis leaf in Newport Beach. Right, adults on an Orange County crape myrtle leave irregular semicircular feeding notches on the leaves.

California citrus, avocado and nursery producers should Diaprepes become established.

The Diaprepes root weevil is longlived and can thrive in agricultural and urban environments; more than 290 species in 59 plant families can support at least one life stage (Simpson et al. 1996). In California, the main vulnerable food crops are orange, grapefruit, lemon and avocado. A Diaprepes infestation primarily would increase production costs for pest treatments to maintain crop yields, and increase harvesting costs to conform to quarantine regulations. While a wide range of ornamental plants is affected by Diaprepes, the main economic impact on the nursery industry would be increased production costs to meet quarantine regulations when shipping plants out of infested regions. Failure to meet quarantine regulations could result in the loss of infested nursery plants, delays in shipping product to customers and possible market losses.

\section{Diaprepes root weevil}

Diaprepes root weevil is native to the Caribbean, where it is considered a pest of citrus, sugar cane and other economically important plants (Woodruff 1968; Martorell 1976). Adult weevils, which live for approximately 4 months, do lit- tle economic damage because they feed on leaf edges, leaving irregular, semicircular notches (Woodruff 1968; Knapp et al. 2000). Only rarely do adults feed on fruit - most commonly papaya and young citrus - again doing little economic damage. If not controlled, feeding damage by larvae on roots and other belowground plant structures causes the most significant economic losses. Larvae are difficult to detect because the aboveground portions of the plant may not show any symptoms until root feeding is extensive. The youngest larvae feed on the finest roots, moving to larger roots as they develop over 5 to 18 months. Their feeding activity destroys feeder and structural roots of the plant.

Larger larvae may girdle the crown of the host plant. Young trees may be killed by larval feeding, and mature trees will decline rapidly, resulting in yield reductions and a greater chance that they will be uprooted in strong winds (McCoy 1999; Stuart et al. 2006). In one infested lemon grove in San Diego County, most of the trees are declining and approximately $10 \%$ blew over during strong winds in 2007 (Gary Bender, UC Cooperative Extension San Diego County, unpublished data). Root damage also provides openings for the entry of Phytophthora root rot, 
compounding the effects of larval damage to roots. In agricultural crops, larval feeding negates the benefits of Phytophthora-resistant rootstocks (Knapp et al. 2001). Florida growers treat to prevent crop losses and have been spending $\$ 400$ per acre annually to protect citrus against the combination of Diaprepes root weevil and Phytophthora (Muraro 2000).

In nursery containers, adult weevils will feed and oviposit (lay eggs) on a large number of ornamental species, and larvae may feed on the roots of these plants, hidden in container soil. Aboveground portions of infested plants may not show any symptoms, but will succumb to larval feeding. In controlled studies, the plant height and trunk diameter of green buttonwood and live oak trees were significantly lower in infested containers than those free of Diaprepes (Diaz et al. 2006).

Despite being capable of strong, short-duration flight, this weevil prefers to "hitchhike" — as adults on plants and as larvae in soil moved by people (Woodruff 1968). Historically, the weevil has moved between and within countries in infested nursery containers (McCoy 1999). In 1964, a single adult weevil was identified from a citrus nursery near Apopka, Fla. (Woodruff 1964). Since then, Diaprepes root weevil has spread to 22 counties in Florida. Much of that spread is attributable to the movement of infested plants by people, despite quarantine regulations in place in Florida since 1968. Enforcement of regulations to contain the Diaprepes root

\section{Despite being capable of strong, short-duration flight, this weevil prefers to "hitchhike" - as adults on plants and as larvae in soil moved by people.}

weevil was frequently difficult (Knapp et al. 2000; Nigg et al. 1998). In 2001, Diaprepes was accidentally introduced into citrus near McAllen, Texas (Skaria and French 2001).

In 2005, Diaprepes was identified in Southern California. Currently, it can be found in five small areas in Orange County, two areas in Los Angeles County, and along the coast of San Diego County in numerous locations from approximately Oceanside to La Jolla. A climate-matching model based on two biological attributes of Diaprepes root weevil (the lower temperature thresholds for oviposition and larval development determined in constant temperature studies) and limited temperature data (11 sites in Orange, Los Angeles, Riverside, Imperial and San Diego counties) suggests that this weevil will only survive in limited areas of Southern California and parts of the San Joaquin Valley (LaPointe et al. 2007). However, the model does not take into account the weevils' ability to adapt to environmental conditions and California's many microclimates. The weevil is already found in areas of Southern California that the model predicted would not support Diaprepes. Strict and effective quarantines are required to prevent its spread into new areas of California via nursery stock.
California is the largest producer of fresh citrus, avocados and nursery products in the United States. Average farm-gate values are $\$ 593$ million for orange, $\$ 86$ million for grapefruit, $\$ 307$ million for lemon and $\$ 332$ million for avocado. With average annual receipts of $\$ 15.7$ billion, the U.S. nursery industry ranks third among all agricultural commodities after corn ( $\$ 26.8$ billion) and soybeans ( $\$ 18.3$ billion) (NASS 2006). California alone accounts for $22 \%$ by value of all U.S. nursery production. All citrus and avocado production and most nursery production in Southern California and the San Joaquin Valley are potentially at risk for Diaprepes; if this weevil becomes established, production would be significantly affected.

\section{Estimating production costs}

Cost estimates begin with determining the appropriate Diaprepres pest controls for California growers, and their costs. Once the costs of individual pest treatments for adults and larvae are estimated, total costs for different treatment scenarios can be calculated and compared. Quarantine costs are then determined based on the interior state quarantine established by the California Department of Food and Agriculture.

Citrus and avocado. For the California citrus and avocado industries,
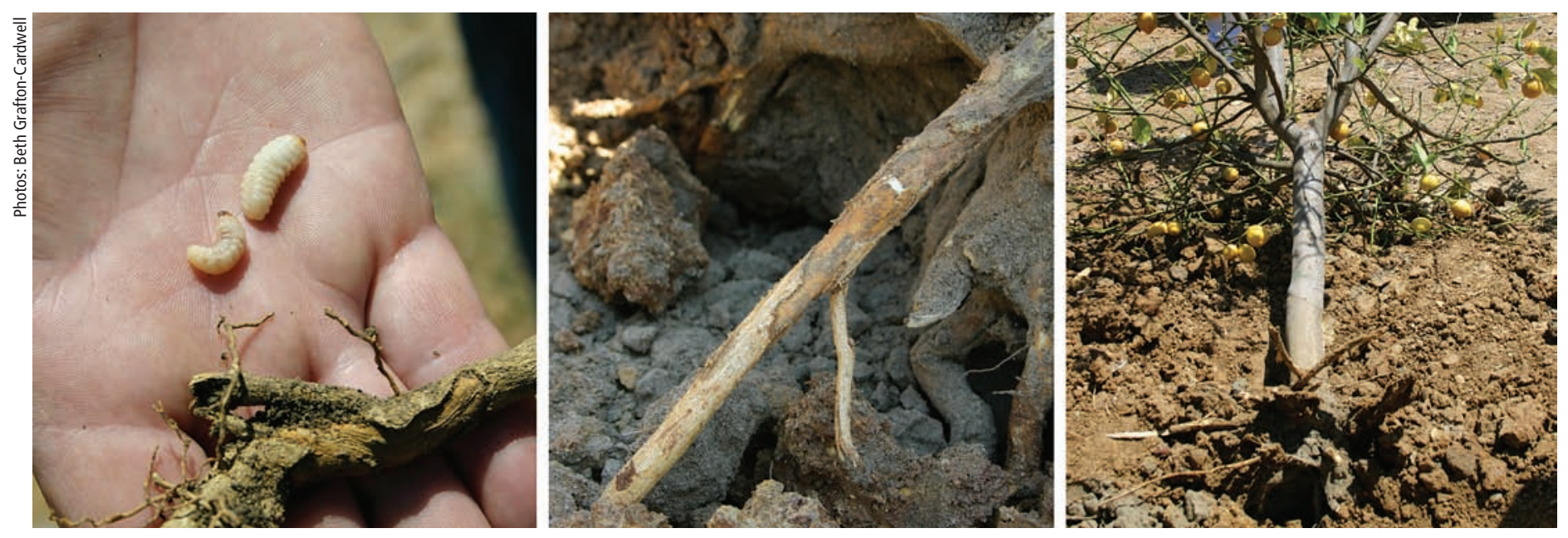

Left, root weevil larvae create "feeding galleries" on lemon tree roots; middle, damaged roots can provide entryways for root-rot organisms; right, a lemon tree infested by Diaprepres was defoliated and had a very small root system. 


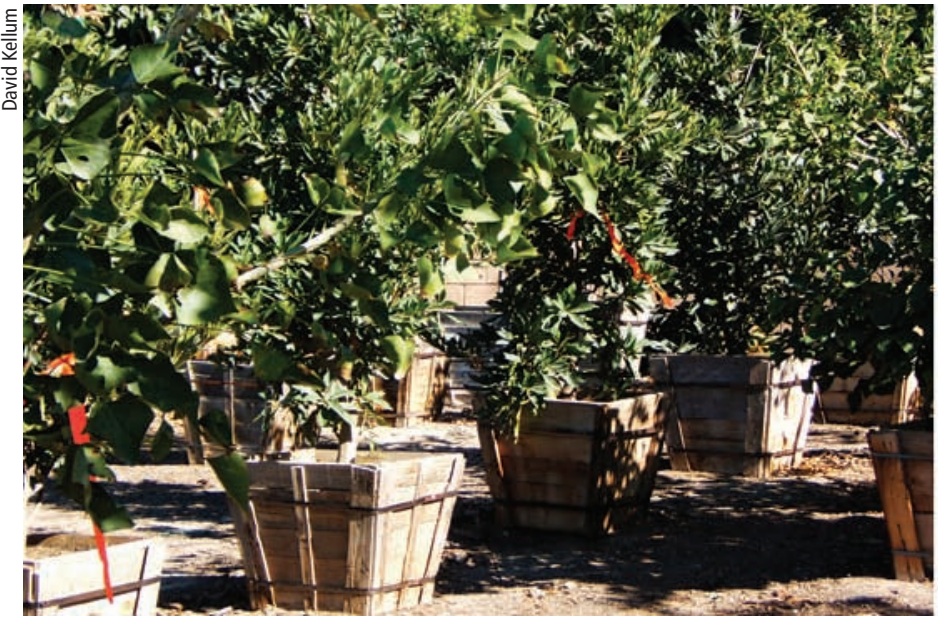

Infested citrus plants in a San Diego County nursery are marked with red flagging tape.

we developed alternative Diaprepres pest-control treatments based on methods used by Florida growers. These treatments were then modified for California's agricultural and climatic conditions. Once the alternatives were determined, costs were estimated by contacting pest-control companies. For alternatives that can be custom applied, we obtained the total cost for materials and applications. For alternatives that are not custom applied, pest control companies provided material costs. The application costs to complete these pest treatment alternatives were taken from the Sample Costs of Production studies by UC Cooperative Extension (http://coststudies.ucdavis. edu/current.php). After treatment costs per acre were estimated, costs were compared to determine the options that California growers would most likely adopt, and an average value over the most likely treatments was calculated. Then the treatment costs per ton for citrus and avocado were estimated by dividing costs per acre by average tons produced per acre.

Quarantine protocols for the citrus and avocado industries were determined through interviews with county personnel from the agricultural commissioner's offices in affected counties, and industry representatives. Costs to meet the quarantine regulations were based on changes in harvesting costs per ton, taken from the Sample Costs of Production budgets for orange, lemon, grapefruit and avocado ( $\mathrm{O}^{\prime}$ Connell et al. 2005a; O'Connell et al. 2005b; Takele and Mauk 1998; Takele, Bender, et al.
2002; Takele, Faber, et al. 2002). Because the most recent budget for grapefruit was prepared in 1998, the cost to harvest grapefruit was inflated to 2005 values using the farm price index for prices paid by farmers (Council of Economic Advisors 2007). The total change in costs was then equal to treatment costs per ton plus quarantine costs per ton.

The effect of increased production costs on growers depends, in addition to the magnitude of the increase, upon its relation to current costs and revenues. A cost increase that represents only $1 \%$ to $2 \%$ of current revenues has different economic implications than one of $15 \%$ to $20 \%$, because it is easier to pass on a $1 \%$ to $2 \%$ share of revenues than a $15 \%$ to $20 \%$ share. For this study, the relative magnitude of the cost increase was determined as a share of revenues by dividing the increased cost per ton by the price per ton. Revenues were used instead of costs at preinfestation levels because they provided a consistent comparison for all crops in this study. The price per ton is a 3-year average for California from 2004 to 2006 (NASS 2006). A 3-year average is sufficiently long to capture seasonal variations in output, but short enough to avoid capturing trend effects.

Nursery industry. Nursery production is made up of diverse operations including potted interior and exterior plants, cut flowers and foliage, bedding, starter flowering and vegetable plants, and Christmas trees. As a result, we estimated the quarantine costs for an "average" nursery that produces potted plants. However, average costs can vary widely. For example, a nursery that produces mostly bedding plants and small shrubs will have a smaller increase in costs than one that produces large landscape trees grown for several years before being sold.

Changes in nursery production costs were estimated only on a per-acre basis, since there was no consistent data on the quantities produced per acre. To place the cost increase due to Diaprepes in context, we also compared it to revenues received per acre. We used the Floriculture and Nursery Yearbook to compile data on revenues per acre (USDA 2006). Due to data limitations, revenues per acre for the affected items could not be separated from total revenues per acre (for example, this figure includes items such as Christmas trees, which are not a regulated host commodity). Consequently, the total revenues per acre for all floriculture and other nursery crops were used as the best approximation of revenues per acre for the items at risk from establishment of Diaprepes in California.

Because of the size of the industries potentially affected by Diaprepes, changes in production costs due to the establishment of an exotic pest may affect market prices as growers pass on higher costs or remove land from production. Higher prices would cause producers in California and the rest of the United States to increase production and consumers to reduce consumption. The establishment of Diaprepes in California would affect both consumers and producers through changes in 


\begin{tabular}{|c|c|c|c|c|c|c|}
\hline \multirow[t]{2}{*}{ Life stage } & Chemical & Application rate & Applications & Materials & Application & Total \\
\hline & & per acre & no. & $\ldots \ldots$ & $\$$ per acre. & $\cdots$ \\
\hline \multirow[t]{3}{*}{ Adult } & Bifenthrin & 40 ounces & 2 & $68^{*}$ & $25^{*}$ & 93 \\
\hline & Carbaryl/oil & 8 pounds & 1 & $63^{*}$ & $25^{*}$ & 88 \\
\hline & Carbaryl/oil & 1.5 gallons & 1 & $68^{*}$ & $25^{*}$ & 93 \\
\hline \multirow[t]{2}{*}{ Larvae } & Imidacloprid & 14 ounces & 2.8 & $148^{*}$ & $5 t$ & 153 \\
\hline & S. riobravis & 1.3 billion each & 3 & $177 *$ & $5+$ & 182 \\
\hline
\end{tabular}

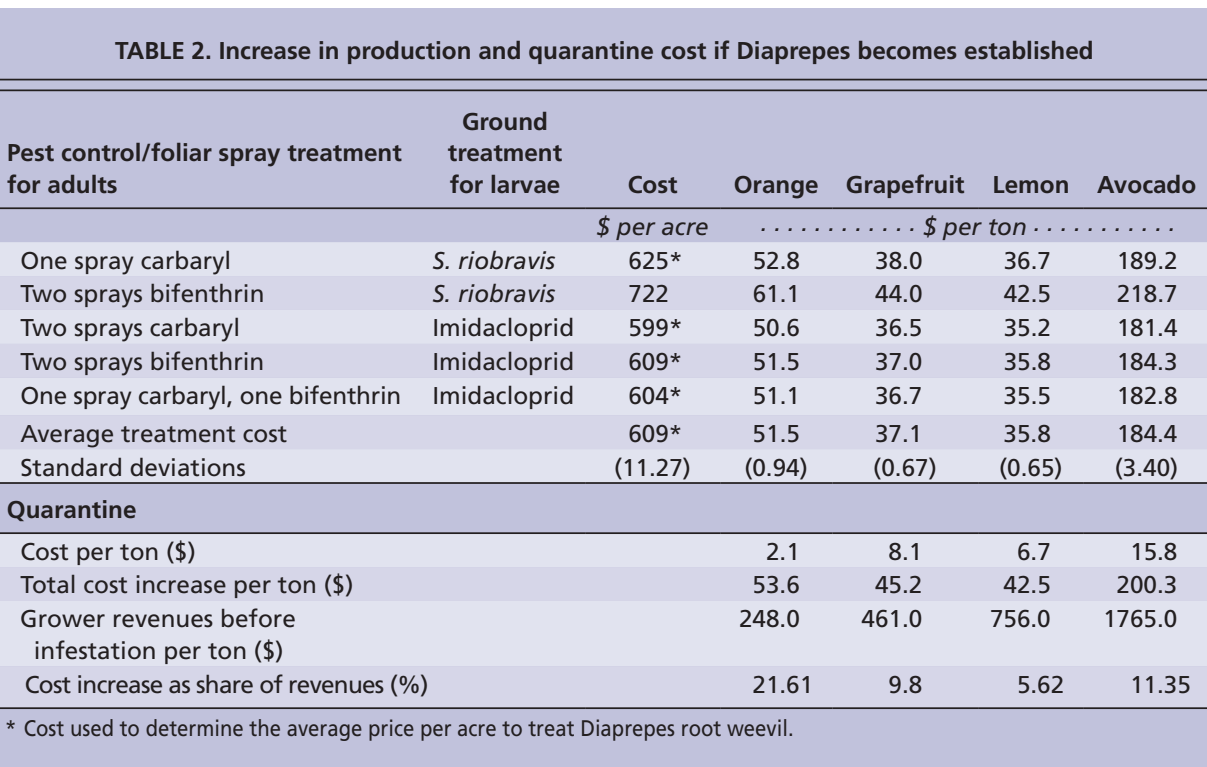

the costs of production, market prices, market supply and consumption; these effects are estimated elsewhere (Jetter 2007). Urban landscapes would also be affected if Diaprepes continues to spread, due to larval feeding that damages the roots of host landscape plants, backyard citrus trees and avocado trees. While important and potentially significant, an estimation of these costs is beyond the scope of this study.

\section{Pest-control alternatives}

Treatments. Diaprepes control in California includes a treatment for adults that live on plant foliage to prevent egg laying, and a treatment for larvae that live in the soil and feed on plant roots (Stansly 2007; Duncan et al. 2007). In Florida's sandy soils, the treatment for Diaprepes is one foliar spray per year using carbaryl to control adults, and releases of a parasitic nematode, Steinernema riobravis, to control larvae (UC IPM Online 2007;
Stansly 2007). If carbaryl is not used, then growers apply two sprays of bifenthrin. After 5 to 6 years, continual releases of $S$. riobravis cause natural enemies of the larvae to build up in the soil, and annual releases of $S$. riobravis may no longer be necessary (Duncan et al. 2007). In heavier soils, the success of $S$. riobravis is more variable. If parasitic nematodes are not as successful in the heavier soils of most citrus-growing areas in California, effective control of the larvae can be accomplished using soil applications of imidacloprid. Along with imidacloprid, two foliar sprays with carbaryl or bifenthrin are applied to target adult weevils.

Costs. The cost for one treatment of bifenthrin or liquid carbaryl plus oil is $\$ 93$ per acre (table 1). Materials and application costs for both chemicals are the same. The cost to treat with the granular formulation of carbaryl plus oil is slightly lower than the liquid formulation due to the lower cost of materials, and the application costs are the same. Costs for single treatments of bifenthrin and carbaryl are similar, but because two treatments of bifenthrin are recommended, the total cost to use bifenthrin is greater than that of carbaryl.

The treatment cost per application for larvae is lower for imidacloprid than for S. riobravis (table 1). Both imidacloprid and S. riobravis are applied through the irrigation system during routine irrigation. The total cost and how well each treatment controls Diaprepes will determine which pestcontrol technique is finally adopted in California. Efficacy is determined by the total cost to treat Diaprepes and how well infestations are managed to prevent yield losses. For example, the cost for $S$. riobravis is greater than imidacloprid; however, if $S$. riobravis is better at controlling Diaprepes larvae and losses are lower, the net cost for $S$. riobravis may be lower. Due to inexperience in treating Diaprepes in California, however, net yield losses for all treatments are unknown; therefore, possible net changes in yields are not included in this analysis.

\section{Evaluating treatment options}

Adult and larva treatment options were paired to determine the alternative costs per acre to treat Diaprepes in citrus and avocado. The cost to use the most effective treatment in sandy soils - a single spray with carbaryl and three releases of S. riobravis - was $\$ 625$ per acre (table 2). If two treatments of bifenthrin are used instead of one treatment of carbaryl, the cost increases to $\$ 722$ per acre. It seems unlikely that growers would adopt this method unless pest resistance to carbaryl is a concern or other treatment considerations arise. If $S$. riobravis is not able to reduce Diaprepes larvae in California below damaging levels, growers may switch to imidacloprid; however, an additional treatment of carbaryl may be needed to manage adult infestations and reduce yield losses. Because the per-treatment costs of applying carbaryl or bifenthrin were similar, costs for the different imidacloprid treatment scenarios were similar. Except for the two sprays of bifenthrin/release $S$. riobravis alternative, control costs for the different 
treatments were close and ranged from $\$ 599$ to $\$ 625$ per acre. Given this similarity, the average of all treatment alternatives, excluding bifenthrin/S. riobravis, was $\$ 609$ per acre, calculated to represent the potential increase in production costs for citrus and avocado growers in the United States.

Dividing the increase in cost per acre by average yields provides the average increase in cost per ton. Yields (tons) per acre varied by crop: orange, 11.8; grapefruit, 16.4; lemon, 17; and avocado, 3.3. With the highest yields per acre, grapefruit and lemon had the lowest increase in cost per ton for pest treatments due to Diaprepes infestations. The increase in average cost per acre would be $\$ 37.10$ per ton for grapefruit and $\$ 35.80$ per ton for lemon (table 2). The cost to grow oranges increased by $\$ 51.50$ per ton. The cost to grow avocados, with the lowest yields per acre, increased $\$ 184.40$ per ton.

Quarantine costs. In addition to treating infestations of Diaprepes, growers will have to meet quarantine regulations to market harvested fruit. Because Diaprepes weevils feed and oviposit on the leaves rather than fruit of susceptible plants, quarantine regulations for citrus and avocado only require that fruit leaving the orchard be free of leaves, twigs and Diaprepes adults in bins of fruit (Nigg et al. 1998). Fruit leaving quarantined areas is subject to inspection. Currently, citrus and avocado are hand-harvested into sacks, and the sacks are then carefully emptied into bins outside the orchard. Leaves that are picked during harvesting of the fruit also end up in the sack. Extra labor can be hired to carefully pick and load the fruit in a manner that does not cause leaves or weevils to fall into the sacks or bins. The extra labor was estimated to increase harvesting costs by $5 \%$ in order to meet postharvest quarantine regulations; the increase in harvesting costs per ton was $\$ 2.10$ for orange, $\$ 8.10$ for grapefruit, $\$ 6.70$ for lemon and $\$ 15.80$ for avocado (table 2).

Total cost changes. The total increase in costs per ton due to the establishment and spread of Diaprepes root weevil in California would be $\$ 53.60$ for orange, $\$ 45.20$ for grapefruit, $\$ 42.50$ for

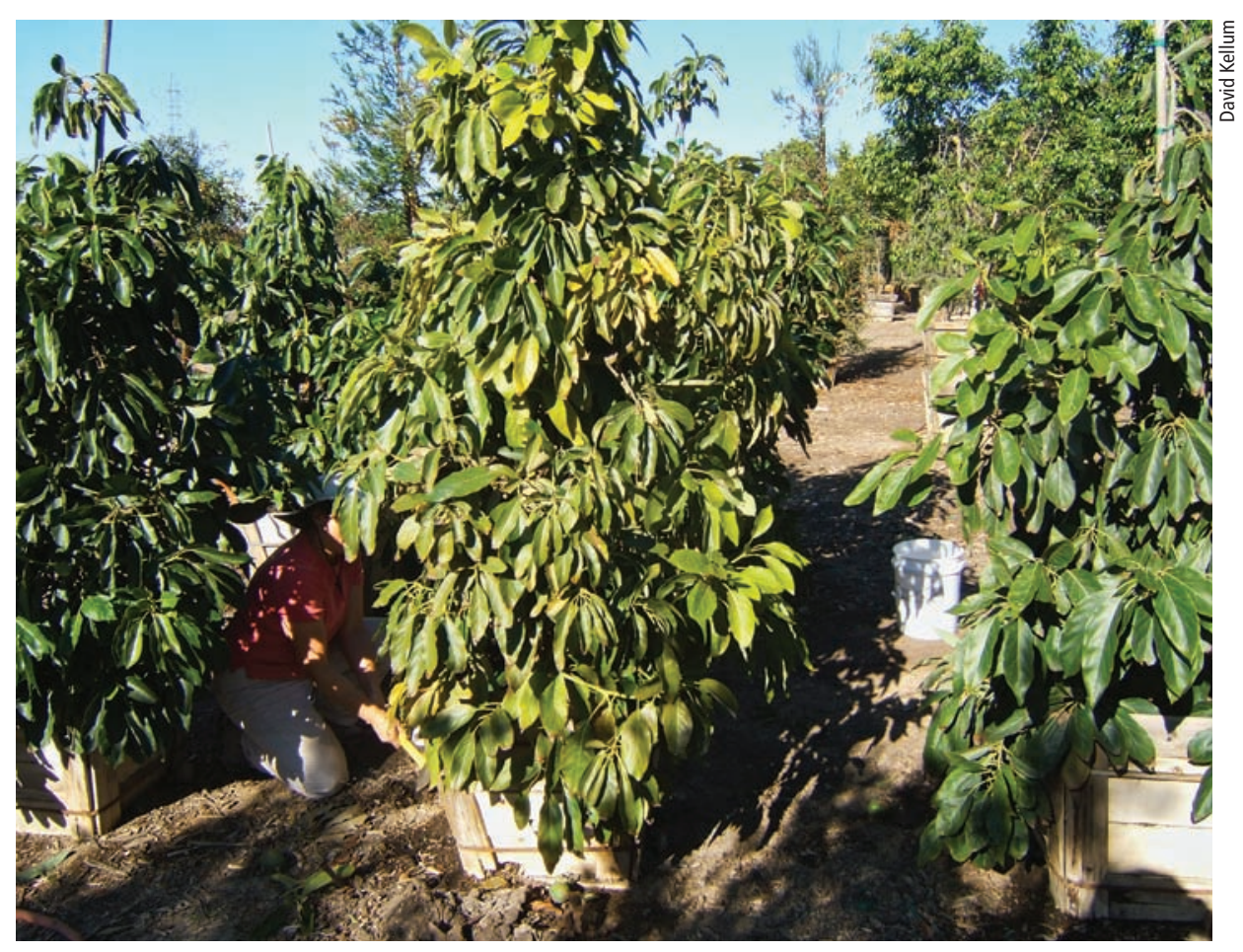

Citrus growing in Southern California orchards and nurseries is at greatest risk of economic damage from Diaprepres. Nurseries infested with the weevil will pay an estimated $\$ 525$ per acre to comply with state-imposed quarantines. Above, the soil of nursery plants is inspected for weevils.

lemon and $\$ 200.00$ for avocado. While the absolute increase in cost per ton was higher for avocado than orange growers, the increase as a share of revenues was lower for avocado (11.35\%) than for orange growers (21.61\%) (table 2). The share for avocados was lower than for oranges because the original cost to produce avocados is higher. Grapefruit and lemon have both the lowest increase in cost per ton and the lowest share of revenues. The increase in production cost as a share of revenues was $9.80 \%$ for grapefruit and $5.62 \%$ for lemon.

\section{Nursery treatment and quarantine}

Quarantine regulations vary depending on whether a nursery is infested with Diaprepes. Nurseries within the quarantine area but without infestations are required to incorporate the granular insecticide bifenthrin into the soil before plants are potted. The granular treatment is good for 2 years, then growers are required to use a soil drench every 6 months. No data was available on how many acres of potted ornamental plants were sold within two years of being potted and after two years; for this analysis, only the initial granular treatment costs were included. Additional costs could be incurred for treatments to meet quarantine regulations for potted plants more than 2 years old, or for repotting into larger pots. We estimated the average cost to meet quarantine regulations for nurseries in the quarantine area - but free of Diaprepes - to be $\$ 300$ per acre.

If a nursery is inspected and found to be infested with Diaprepes, an additional foliar spray treatment with carbaryl is required before plants can be

\begin{tabular}{|c|c|c|c|c|c|c|}
\hline & \multicolumn{3}{|c|}{ Clean nursery } & \multicolumn{3}{|c|}{ Infested nursery } \\
\hline & Floriculture & Other & Combined & Floriculture & Other & Combined \\
\hline Revenue per acre (\$) & 93,914 & 41,158 & 66,709 & 93,914 & 41,158 & 66,709 \\
\hline $\begin{array}{l}\text { Cost of quarantine protocols } \\
\text { per acre }(\$)\end{array}$ & 300 & 300 & 300 & 525 & 525 & 525 \\
\hline Cost increase as share of revenues (\%) & 0.32 & 0.73 & 0.45 & 0.39 & 0.88 & 0.55 \\
\hline
\end{tabular}


shipped. All plants must be sprayed. The additional cost for a nursery infested with Diaprepes was an estimated \$225 per acre and the total cost to meet quarantine regulations was $\$ 525$ per acre.

Total average revenues per acre are $\$ 93,914$ for floriculture industries and $\$ 41,158$ for other nursery production (table 3) (USDA 2006). The weighted average revenue of both nursery industries is $\$ 66,709$ per acre. The increase in total cost as a share of revenues, to meet quarantine regulations for nurseries in a quarantine area but free of Diaprepes, is $0.32 \%$ for floriculture and $0.73 \%$ for other nursery industries, for an average of $0.45 \%$. The cost increase for infested nurseries as a share of revenues is larger due to foliar treatments. The $\$ 525$ increase in production cost for infested nurseries is $0.39 \%$ of total revenues for floriculture, $0.88 \%$ for other nurseries and $0.55 \%$ for the industries combined (table 3). While growers with infestations pay more, higher costs as a share of revenue are still less than $1 \%$.

\section{Implications for growers, consumers}

Since the eradication program was discontinued, the quarantine program is critical to keep Diaprepres from spreading to other parts of California. If left untreated, this destructive weevil - a "hitchhiker" in plants, bins of fruit, and even inside cars and trucks could cause serious production declines for the California citrus, avocado and ornamental nursery industries, as well as kill plants in urban, public and natural areas. Rather than let plants die or production decline, growers in Florida treat for Diaprepes, and growers in California will also need to treat.

To protect crops and meet quarantine regulations, producers of citrus, avocado and ornamental plants will need to pay hundreds of dollars in treatment costs per acre or switch to different crops or economic activities. The final effect on each industry will depend upon the magnitude of the cost changes relative to current costs and revenues. Industries for which the change in costs is large relative to current revenues will have to make greater adjustments in price and acreage than industries with smaller increases. Ultimately, given the size of these industries and their contribution to total U.S. production, product markets will also be affected, causing consumers to pay more for fresh citrus, avocado and landscaping plants.

K.M. Jetter is Assistant Research Economist, UC Agricultural Issues Center; and K. Godfrey is Senior Environmental Research Scientist, California Department of Food and Agriculture (CDFA), Biological Control Program, Sacramento. This study was paid for by a grant from the CDFA Pest Detection and Emergency Projects Branch.

\section{References}

Council of Economic Advisors. 2007. Economic Report of the President. Washington, DC. Table B101. www.gpoaccess.gov/eop/index.html.

Diaz AP, Mannion C, Schaffer B. 2006. Effect of root feeding by Diaprepes abbreviatus (Coleoptera: Curculionidae) larvae on leaf gas exchange and growth of three ornamental tree species. Hort Entomol 99:811-21.

Duncan LW, Graham JH, Zellers J, et al. 2007. Food web responses to augmenting the entomopathogenic nematodes in bare and animal manure-mulched soil. J Nematol 39:176-89.

Jetter K. 2007. An Economic Analysis of the Establishment of Diaprepes Root Weevil On Citrus, Avocados and Nursery Industries in California. Final Report prepared for the California Department of Food and Agriculture. UC Agricultural Issues Center, Davis, CA. 16 p.

Knapp J, Nigg H, Simpson S, et al. 2001. Diaprepes Root Weevil: A Pest of Citrus, Ornamentals and Root Crops in Florida. University of Florida, Institute of Food and Agricultural Science, Lake Alfred, FL. ENY645. http://edis.ifas.ufl.edu

Knapp J, Simpson S, Pena J, Nigg H. 2000. Diaprepes Root Weevil: What Floridians Need to Know. University of Florida, Institute of Food and Agricultural Science, Lake Alfred, FL. ENY-640. http://edis.ifas.ufl.edu.

LaPointe S, Borchert D, Hall D. 2007. Effect of low temperatures on mortality and oviposition in conjunction with climate mapping to predict spread of the root weevil Diaprepes abbreviatus and introduced natural enemies. Environ Entomol 36:73-82.

Martorell L. 1976. Annotated Food Plant Catalog of the Insects of Puerto Rico. University of Puerto Rico Agricultural Experiment Station, Department of Entomology. $303 p$

McCoy C. 1999. Arthropod pests of citrus roots. In: Timmer L, Duncan L (eds.). Citrus Health Management. St. Paul, MN: APS Pr. p 149-56.

Muraro R. 2000. Cost benefit analysis for controlling Diaprepes. In: Futch S (ed.). Diaprepes Short Course. Citrus Research and Education Foundation, Lake Alfred, FL. 5 p.

[NASS] National Agricultural Statistics Service. 2006 Agricultural Statistics 2005. United States Department of Agriculture, Washington, DC

Nigg H, Simpson S, Donaldson-Fortier G. 1998. A close look at Diaprepes: The worst long-term threat to Florida citrus? Citrus Ind (April):3-5.

O'Connell N, Kallsen CE, Freeman MW, et al. 2005a. Sample Costs to Establish an Orange Orchard and Produce. San Joaquin Valley - South. UC Cooperative Extension, Davis, CA. www.agecon.ucdavis.edu. 24 p.

O'Connell N, Kallsen CE, Freeman MW, et al. 2005b. Sample Costs to Establish an Orchard and Produce Lemons. San Joaquin Valley - South. UC Cooperative Extension, Davis, CA. www.agecon.ucdavis.edu. 24 p.

Simpson S, Nigg H, Coile N, Adair R. 1996. Diaprepes abbreviatus (Coleoptera: Curculionidae): Host-plant associations. Environ Entomol 25:333-49.

Skaria M, French J. 2001. Phytophthora disease of citrus associated with root weevils in Texas. Phytopathol 91 (Suppl):S203.

Stansly P. 2007. Options for Management of Diaprepes in Florida Citrus. Southwest Florida Research and Education Center, University of Florida - IFAS. 22 p. www.imok.ufl. edu/entlab/pres/facts2k.

Stuart R, McCoy C, Castle W, et al. 2006. Diaprepes, Phytophthora and hurricanes: Rootstock selection and pesticide use affect growth and survival of 'Hamlin' orange trees in a central Florida citrus grove. Proc Florida State Hort Soc 119:128-35.

Takele E, Bender GS, Lobo R, Mauk P. 2002. Avocado Sample Establishment and Production Costs and Profitability Analysis for San Diego and Riverside Counties. UC Cooperative Extension, Davis, CA. www.agecon. ucdavis.edu.

Takele E, Faber B, Chambers S. 2002. Avocado Sample Establishment and Production Costs and Profitability Analysis for Ventura and Santa Barbara Counties, California. UC Cooperative Extension, Davis, CA. www.agecon.ucdavis.edu.

Takele E, Mauk P. Establishment and Production Costs: Grapefruit, Western Riverside County. UC Cooperative Extension, Davis, CA. 1998. www.agecon.ucdavis. edu.

UC IPM Online. 2007. A New Pest in California, Diaprepes Root Weevil (Citrus Root Weevil): Provisional Treatment Guidelines for Citrus in Quarantine Areas. UC ANR. 3 p. www.ipm.ucdavis.edu/EXOTIC/ diaprepescitrus.html.

[USDA] US Department of Agriculture. 2006. Floriculture and Nursery Yearbook. Economic Research Service, Washington, DC. www.ers.usda.gov/ Publications/Flo.

Woodruff R. 1964. A Puerto Rican weevil new to the United States (Coleoptera: Curculionidae). Florida Department of Agriculture Division of Plant Industry. Entomol Circ 30:1-2.

Woodruff R. 1968. The present status of a West Indian weevil (Diaprepes abbreviatus L.) in Florida (Coleoptera: Curculionidae). Florida Department of Agriculture Division of Plant Industry. Entomol Circ 77. 